National and Global Petroleum Assessment

\title{
Assessment of Continuous Oil and Gas Resources in the Mississippian Delle Phosphatic Member of the Woodman Formation in the Eastern Great Basin Province of Nevada, Utah, and Idaho, 2019
}

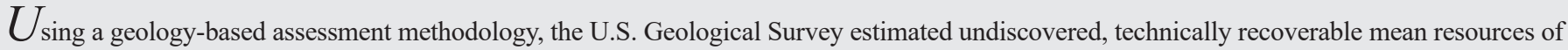
144 million barrels of shale oil and 559 billion cubic feet of shale gas in the Mississippian Delle Phosphatic Member of the Woodman Formation in the Eastern Great Basin Province of Nevada, Utah, and Idaho.

\section{Introduction}

The U.S. Geological Survey (USGS) quantitatively assessed the potential for undiscovered, technically recoverable continuous oil and gas resources in the Mississippian Delle Phosphatic Member of the Woodman Formation in the Eastern Great Basin Province of Nevada, Utah, and Idaho (Anna and others, 2007) (fig. 1). Eastward thrusts associated with arc-continent collision (Antler orogeny) during the Late Devonian-Mississippian resulted in the formation of the Antler foreland basin east of the thrust belt (Speed and Sleep, 1982; Giles and Dickinson, 1995). The Antler foreland basin was characterized by a foredeep basin, forebulge, and back-bulge basin (Jewell and others, 2000). The organic-rich Delle Phosphatic Member was deposited in the Antler back-bulge basin, an area that was subject to changes in sea level, anoxia, and preservation of organic matter (Sandberg and others, 1980; Nichols and Silberling, 1990; Jewell and others, 2000; Saltzman, 2003). The Delle Phosphatic Member was buried by varying thicknesses of Upper Pennsylvanian to lower Permian sediments of the Oquirrh-Wood River Basin (Jordan and Douglass, 1980; Sandberg and Gutschick, 1984; Erskine, 1997; Geslin, 1998). Differential burial largely controlled the level of thermal maturation of the Delle Phosphatic Member (Sandberg and Gutschick, 1984), which ranges from being in the oil to being in the dry-gas generation windows across northwestern Utah and eastern Nevada. Structural deformation during the Mesozoic and early Paleogene and basin and range extension in the Neogene further complicated the structural setting of the Delle Phosphatic Member.

\section{Total Petroleum System and Assessment Units}

The USGS defined the Delle Phosphatic Member Total Petroleum System (TPS) with the Delle Phosphatic Member Shale Oil Assessment Unit (AU) and the Delle Phosphatic Member Shale Gas AU within this TPS. The Delle Phosphatic Member is the basal member of several stratigraphic units - the Woodman Formation, Chainman Formation, and Deseret Limestone (Chidsey, 2013). The Delle Phosphatic Member contains as much as 8 weight percent organic carbon, presumably has Type IIS kerogen, and is as much as 60 meters thick (Sandberg and Gutschick, 1984). Correlative shales of the basal Chainman Formation can have up to 8 weight percent organic carbon, are dominated by Type II kerogen, have hydrogen indices as much as 400 milligrams of hydrocarbon per gram of organic carbon, and can be overpressured (Sandberg and others, 1980; Poole and Claypool, 1984; Anna and others, 2007).

The geologic model for the Mississippian Delle Phosphatic Member is for the organic-rich phosphatic shales to have been differentially buried by Mississippian Antler foreland basin sediments and Pennsylvanian and Permian sediments of the Oquirrh Basin, which would have placed the Delle Phosphatic Member into the oil, wet-gas, and dry-gas windows in a spatially complex pattern (Sandberg and Gutschick, 1984). In this model, part of the gas would have been retained within the shales following generation, expulsion, migration, and structural deformation (several phases), similar to the Phosphoria Formation in the Wyoming Thrust Belt (Schenk and others, 2018). There is considerable uncertainty on the retention of oil and gas within the shales of the Delle Phosphatic Member given the tectonic history, as shown by the assigned geologic risk (table 1).

The assessment input data are also summarized in table 1. Well drainage areas, success ratios, and estimated ultimate recoveries are based on U.S. analogs.

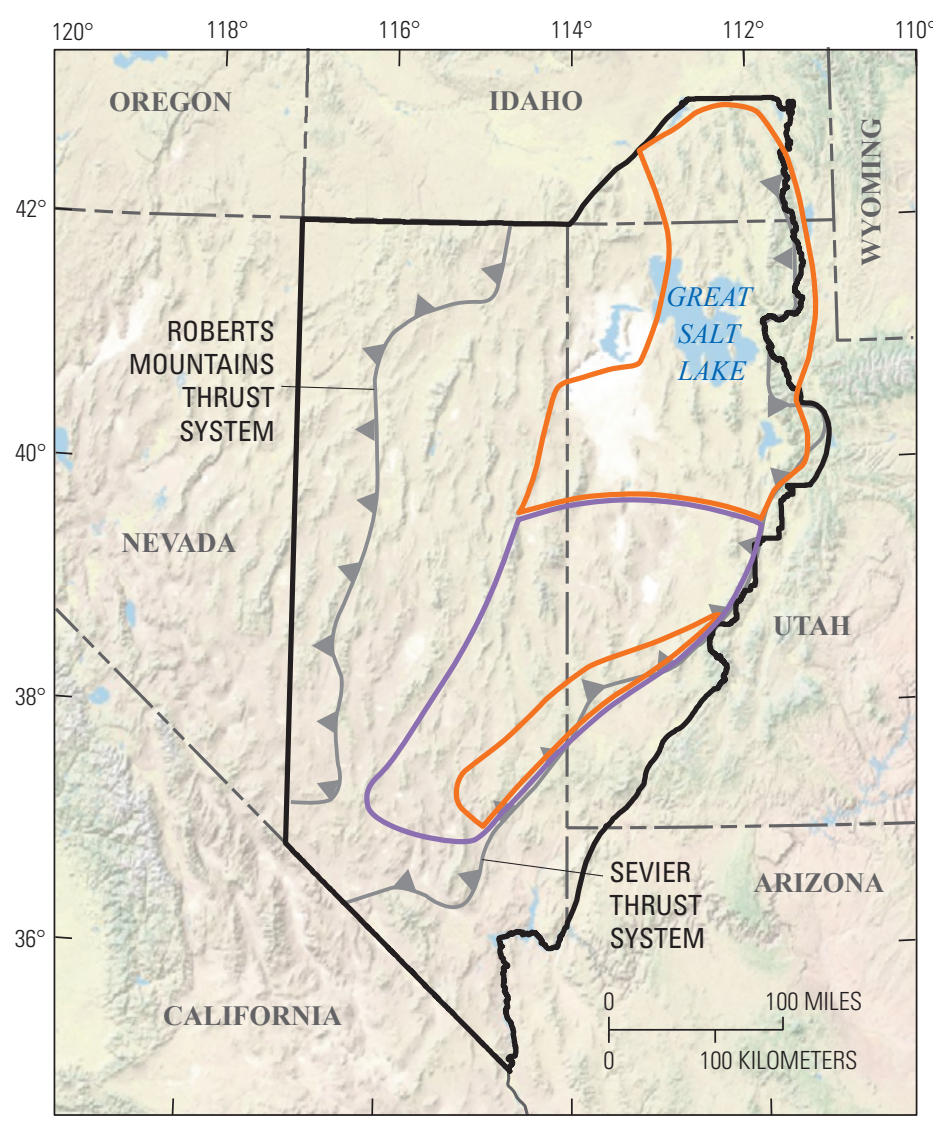

Base map from

U.S. Department of the Interior National Park Service

EXPLANATION
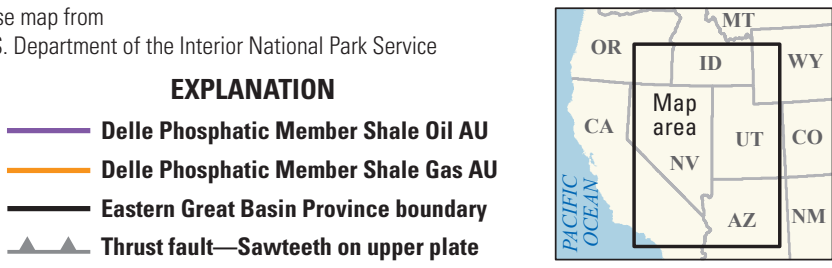

Figure 1. Map showing the location of two assessment units in the Mississippian Delle Phosphatic Member of the Woodman Formation in the Eastern Great Basin Province of Nevada, Utah, and Idaho. 
Table 1. Key input data for two continuous assessment units in the Delle Phosphatic Member of the Eastern Great Basin Province of Nevada, Utah, and Idaho.

[AU, assessment unit; \%, percent; EUR, estimated ultimate recovery per well; MMBO, million barrels of oil; BCFG, billion cubic feet of gas. Well drainage area, success ratio, and EUR are defined partly using U.S. shale-oil and shale-gas analogs. The average EUR input is the minimum, median, maximum, and calculated mean. Shading indicates not applicable]

\begin{tabular}{|c|c|c|c|c|c|c|c|c|}
\hline \multirow{2}{*}{$\begin{array}{l}\text { Assessment input data- } \\
\text { Continuous AUs }\end{array}$} & \multicolumn{4}{|c|}{ Delle Phosphatic Member Shale Oil AU } & \multicolumn{4}{|c|}{ Delle Phosphatic Member Shale Gas AU } \\
\hline & Minimum & Mode & Median & Calculated mean & Minimum & Mode & Maximum & Calculated mean \\
\hline Potential production area of AU (acres) & 1,000 & $5,759,000$ & $11,518,000$ & $5,759,333$ & 1,000 & $8,833,000$ & $17,666,000$ & $8,833,333$ \\
\hline Average drainage area of wells (acres) & 80 & 120 & 160 & 120 & 80 & 120 & 160 & 120 \\
\hline Success ratio $(\%)$ & 5 & 15 & 25 & 15 & 5 & 15 & 25 & 15 \\
\hline Average EUR (MMBO, oil; BCFG, gas) & 0.01 & 0.03 & 0.1 & 0.034 & 0.04 & 0.07 & 0.1 & 0.071 \\
\hline AU probability & 0.6 & & & & 0.6 & & & \\
\hline
\end{tabular}

\section{Undiscovered Resources Summary}

The USGS quantitatively assessed the potential for continuous oil and gas resources within the Mississippian Delle Phosphatic Member of the Woodman Formation (table 2). The estimated undiscovered mean resources are 144 million barrels of oil (MMBO) with an F95-F5 range from 0 to $472 \mathrm{MMBO}, 559$ billion cubic feet of gas (BCFG) with an F95-F5 range from 0 to 1,708 BCFG, and 2 million barrels of natural gas liquids (MMBNGL) with an F95-F5 range from 0 to 6 MMBNGL.

Table 2. Results for two continuous assessment units in the Delle Phosphatic Member of the Eastern Great Basin Province of Nevada, Utah, and Idaho.

[MMBO, million barrels of oil; BCFG, billion cubic feet of gas; NGL, natural gas liquids; MMBNGL, million barrels of natural gas liquids. Results shown are fully risked estimates. F95 represents a 95-percent chance of at least the amount tabulated; other fractiles are defined similarly. Fractiles are additive under the assumption of perfect positive correlation. Shading indicates not applicable]

\begin{tabular}{|c|c|c|c|c|c|c|c|c|c|c|c|c|c|c|}
\hline \multirow{3}{*}{$\begin{array}{l}\text { Total petroleum system and } \\
\text { assessment units (AU) }\end{array}$} & \multirow{3}{*}{$\begin{array}{l}\text { AU } \\
\text { prob- } \\
\text { ability }\end{array}$} & \multirow{3}{*}{$\begin{array}{c}\text { Accu- } \\
\text { mulation } \\
\text { type }\end{array}$} & \multicolumn{12}{|c|}{ Total undiscovered resources } \\
\hline & & & \multicolumn{4}{|c|}{ Oil (MМBO) } & \multicolumn{4}{|c|}{ Gas (BCFG) } & \multicolumn{4}{|c|}{ NGL (MMBNGL) } \\
\hline & & & F95 & F50 & F5 & Mean & F95 & F50 & F5 & Mean & F95 & F50 & F5 & Mean \\
\hline \multicolumn{15}{|c|}{ Delle Phosphatic Member Total Petroleum System } \\
\hline Delle Phosphatic Member Shale Oil AU & 0.6 & Oil & 0 & 100 & 472 & 144 & 0 & 57 & 293 & 86 & 0 & 0 & 1 & 0 \\
\hline Delle Phosphatic Member Shale Gas AU & 0.6 & Gas & & & & & 0 & 383 & 1,415 & 473 & 0 & 1 & 5 & 2 \\
\hline Total undiscovered continuous resources & & & 0 & 100 & 472 & 144 & 0 & 440 & 1,708 & 559 & 0 & 1 & 6 & 2 \\
\hline
\end{tabular}

\section{References Cited}

Anna, L.O., Roberts, L.N.R., and Potter, C.J., 2007, Geologic assessment of undiscovered oil and gas resources in the Paleozoic-Tertiary Composite Total Petroleum System of the eastern Great Basin, Nevada and Utah, chap. 2 of U.S. Geological Survey Eastern Great Basin Assessment Team, Geologic assessment of undiscovered oil and gas resources of the Eastern Great Basin Province, Nevada, Utah, Idaho, and Arizona: U.S. Geological Survey Digital Data Series DDS-69-L, 50 p.

Chidsey, T.C., Jr., ed., 2013, Paleozoic shale-gas resources of the Colorado Plateau and eastern Great Basin, Utah-Multiple frontier exploration opportunities: Salt Lake City, Utah Geological Survey Bulletin 136, 241 p.

Erskine, M.C., 1997, The Oquirrh basin revisited: The American Association of Petroleum Geologists Bulletin, v. 81, no. 4, p. 624-636.

Geslin, J.K., 1998, Distal ancestral Rocky Mountains tectonism-Evolution of the Pennsylvanian-Permian Oquirrh-Wood River basin, southern Idaho: Geological Society of America Bulletin, v. 110, no. 5, p. 644-663.

Giles, K.A., and Dickinson, W.R., 1995, The interplay of eustasy and lithospheric flexure in forming stratigraphic sequences in foreland settings - An example from the Antler foreland, Nevada and Utah, in Dorobek, S.L., and Ross, G.M., eds., Stratigraphic evolution of foreland basins: Society of Economic Paleontologists and Mineralogists [now the Society for Sedimentary Geology], Special Publication No. 52, p. 187-211.

Jewell, P.W., Silberling, N.J., and Nichols, K.M., 2000, Geochemistry of the Mississippian Delle phosphatic event, eastern Great Basin, U.S.A: Journal of Sedimentary Research, v. 70 , no. 5 , p. $1222-1233$

Jordan, T.E., and Douglass, R.C., 1980, Paleogeography and structural development of the Late Pennsylvanian to Early Permian Oquirrh Basin, northwestern Utah, in Fouch, T.D., and Magathan, E.R., eds., Paleozoic paleogeography of the west-central United States-Proceedings of the Rocky Mountain Paleogeography Symposium 1, June 1980, Denver, Colo. Society of Economic Paleontologists and Mineralogists [now the Society for Sedimentary Geology], Rocky Mountain Section, Paleogeography Symposium No. 1, p. 217-238.
Nichols, K.M., and Silberling, N.J., 1990, The Delle Phosphatic Member-An anomalous phosphatic interval in the Mississippian (Osagean-Meramecian) shelf sequence of central Utah: Geology, v. 18, no. 1, p. 46-49.

Poole, F.G., and Claypool, G.E., 1984, Petroleum source-rock potential and crude-oil correlation in the Great Basin, in Woodward, J., Meissner, F.F., and Clayton, J.L., eds., Hydrocarbon source rocks of the greater Rocky Mountain region: Denver, Colo., Rocky Mountain Association of Geologists, p. 179-230.

Saltzman, M.R., 2003, Organic carbon burial and phosphogenesis in the Antler foreland basin-An out-of-phase relationship during the Lower Mississippian: Journal of Sedimentary Research, v. 73 , no. 6, p. 844-855.

Sandberg, C.A., and Gutschick, R.C., 1984, Distribution, microfauna, and source-rock potential of Mississippian Delle Phosphatic Member of Woodman Formation and equivalents, Utah and adjacent states, in Woodward, J., Meissner, F.F., and Clayton, J.L., eds., Hydrocarbon source rocks of the greater Rocky Mountain region: Denver, Colo., Rocky Mountain Association of Geologists, p. 135-178.

Sandberg, C.A., Poole, F.G., and Gutschick, R.C., 1980, Devonian and Mississippian stratigraphy and conodont zonation of Pilot and Chainman Shales, Confusion Range, Utah, in Fouch, T.D., and Magathan, E.R., eds., Paleozoic paleogeography of west-central United States-Proceedings of the Rocky Mountain Paleogeography Symposium 1, June 1980, Denver, Colo.: Society of Economic Paleontologists and Mineralogists [now the Society for Sedimentary Geology], Rocky Mountain Section, p. 71-79.

Schenk, C.J., Mercier, T.J., Tennyson, M.E., Woodall, C.A., Finn, T.M., Pitman, J.K., Gaswirth, S.B., Marra, K.R., Le, P.A., Klett, T.R., and Leathers-Miller, H.M., 2018, Assessment of continuous gas resources in the Phosphoria Formation of the Wyoming Thrust Belt Province, Wyoming, Idaho, and Utah, 2017: U.S. Geological Survey Fact Sheet 2018-3001, 2 p.

Speed, R.C., and Sleep, N.H., 1982, Antler orogeny and foreland basin-A model: Geological Society of America Bulletin, v. 93, no. 9, p. 815-828.

\section{For More Information}

Assessment results are also available at the USGS Energy Resources Program website at https://energy.usgs.gov.

\section{Delle Phosphatic Member Assessment Team}

Christopher J. Schenk, Tracey J. Mercier, Thomas M. Finn, Kristen R. Marra, Phuong A. Le, Michael E. Brownfield, and Heidi M. Leathers-Miller 